\title{
RENAL INVOLVEMENT IN HUMAN RABIES: CLINICAL MANIFESTATIONS AND AUTOPSY FINDINGS OF NINE CASES FROM NORTHEAST OF BRAZIL
}

\author{
Elizabeth De Francesco DAHER(1,2), Geraldo Bezerra da SILVA JÚNIOR(1), Marúsia Thomaz FERREIRA(1), Fernando Antonio de Sousa BARROS(1), \\ Tiago Magalhães GURGEL(3) \& Régia Maria do Socorro Vidal PATROCíNIO(3)
}

\begin{abstract}
SUMMARY
A retrospective study was conducted in nine patients with rabies admitted to a hospital of Fortaleza, Brazil. Autopsy was performed in all cases. The ages ranged from three to 81 years and six were males. They all were bitten by dogs. The time between the accident and the hospital admission ranged from 20 to 120 days (mean $45 \pm 34$ days). The time until death ranged from one to nine days (mean $3.3 \pm 5.5$ days). The signs and symptoms presented were fever, hydrophobia, aerophobia, agitation, disorientation, dyspnea, sialorrhea, vomiting, oliguria, sore throat, pain and hypoesthesia in the site of the bite, headache, syncope, cough, hematemesis, mydriasis, hematuria, constipation, cervical pain and priapism. In three out of six patients, there was evidence of acute renal failure, defined as serum creatinine $\geq 1.4 \mathrm{mg} / \mathrm{dL}$. The post-mortem findings in the kidneys were mild to moderate glomerular congestion and mild to intense peritubular capillary congestion. Acute tubular necrosis was seen in only two cases. This study shows some evidence of renal involvement in rabies. Histopathologic findings are nonspecific, so hemodynamic instability, caused by autonomic dysfunction, hydrophobia and dehydration must be responsible for acute renal failure in rabies.
\end{abstract}

KEYWORDS: Rabies; Clinical manifestations; Acute renal failure; Pathology; Autopsy.

\section{INTRODUCTION}

Rabies has been considered one of the greatest terrors of humankind throughout history ${ }^{7}$. It has a worldwide distribution, being reported in all continents, except Antarctica ${ }^{21}$. In Brazil, the disease is endemic, with an incidence estimated at 0.05 per 100,000 population. The northeast region was responsible for more than $50 \%$ of all cases registered in the country from 1986 to $2001^{14}$.

Rabies is an acute viral encephalomyelitis caused by etiologic agents in the family Rhabdoviridae, genus Lyssavirus $2,8,18,21,26$. Transmission occurs through animal bites, mainly by $\operatorname{dog} s^{2,10,21}$. The incubation period ranges from one to three months, but the disease can occur years after the exposure ${ }^{21}$.

Renal involvement in rabies is not well described in the literature. Acute renal failure in rabies seems to be rare, with few documented cases of oliguria, without demonstration of alterations in serum creatinine or glomerular filtration rate $^{4,13}$. The involvement of extraneural organs in rabies has been reported, including skeletal and cardiac muscle, adrenal glands and pancreas ${ }^{11,23}$. At the present time no study has described histopathologic changes in renal tissue in rabies. The studies in which the kidneys were examined found no abnormality ${ }^{11,15}$. A recent publication has demonstrated the transmission of rabies through organ transplantation, including kidney transplantation ${ }^{22}$. Lymphohistiocytic infiltrates have been found involving the peripheral nerves, heart and kidneys in some patients. The immunohistochemical staining of rabies virus antigens was positive in peripheral nerves of the kidney ${ }^{22}$.

The objective of this paper was to describe the clinical manifestations and histopathologic findings of renal involvement in recent cases of rabies reported in our region.

\section{MATERIAL AND METHODS}

A retrospective study was conducted with all the patients with confirmed diagnosis of rabies admitted from January 2000 to December 2003 at the São José Hospital of Infectious Diseases in Fortaleza, northeast of Brazil. During the study period nine cases of the disease were registered in this hospital, which is the largest infectious disease hospital of our region. Autopsy was performed in all cases at the Department of Pathology of the Federal University of Ceará. The time between death and autopsy was approximately six hours. These cases had the kidneys stored for histologic analysis. The epidemiologic and clinical data from these patients was reviewed.

The parameters used to evaluate patients' clinical features were: 


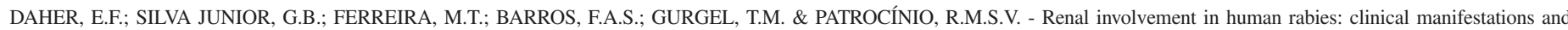
autopsy findings of nine cases from northeast of Brazil. Rev. Inst. Med. trop. S. Paulo, 47(6):315-320, 2005.

time between the accident and hospital admission, time of hospitalization, maximum and minimum systolic and diastolic blood pressure, maximum temperature, heart rate and respiratory rate (during the first $24 \mathrm{~h}$ after admission). All signs and symptoms presented at admission and during hospital stay were recorded. Also analyzed were the patient's social status, age, gender and site of the bite.

Serum concentration of urea, creatinine, potassium, sodium and complete blood count were recorded at admission. Serum urea and creatinine after admission were not sequentially performed in the majority of cases. The treatment instituted was also analyzed. Acute renal failure (ARF) was defined as an increase of serum creatinine concentration by more than $50 \%$ or greater than $0.5 \mathrm{mg} / \mathrm{dL}$ above baseline $^{5}$. It was then difficult to define ARF based on clinical and laboratory data, because the baseline values of creatinine were not known. Some patients could have developed ARF during hospital stay, but the available serum creatinine value was from admission. ARF was confirmed after autopsy, in the cases in which acute tubular necrosis was identified. Oliguria was defined as urine volume less than 400 $\mathrm{mL} /$ day in adults and less than $0.5 \mathrm{~mL} / \mathrm{kg} / \mathrm{h}$ in children.

The stored kidney fragments were collected and sections 4-5 $\mu \mathrm{m}$ thick of paraffin-embedded tissues were stained with hematoxylin and eosin (H\&E) for standard histologic analysis.

The protocol of this study was approved by The Ethical Committee of the São José Hospital of Infectious Diseases. The statistical analysis was done through the program Epi Info 2002. The results are expressed as mean $\pm \mathrm{SD}$.

\section{RESULTS}

All nine patients had the diagnosis of rabies established on the basis of clinical manifestations, laboratory tests (immunofluorescence technique for rabies antigen detection in patients' saliva) and postmortem findings (which confirmed the diagnosis through identification of Negri's bodies in CNS tissue).
The ages ranged from three to 81 years (mean $31 \pm 26$ years), six were male and three female; five were from Fortaleza City and four were from the countryside of Ceará State. All the patients were from lower socioeconomic classes. Their occupations were students (four cases), maids (three cases), waiter (one case) and bricklayer (one case). They all were bitten by dogs. The sites of the bites were the hands (five cases), the face (two cases), the arms (one case) and the legs (one case). All the patients died.

The time between the accident and admission to the hospital ranged from 20 to 120 days (mean $45 \pm 34$ days). The time until death ranged from one to 9 days (mean $3.1 \pm 5.5$ days). The signs and symptoms presented at admission were fever (eight cases), hydrophobia (eight cases), agitation (eight cases), aerophobia (five cases), disorientation (five cases), dyspnea (five cases), sialorrhea (four cases), vomiting (three cases), oliguria (three cases), sore throat (three cases), pain and hypoesthesia in the site of the bite (two cases). Headache, syncope, cough, hematemesis, mydriasis, hematuria, constipation, cervical pain and priapism were also present in one case each. The laboratory findings at hospital admission are summarized in Table 1.

The average maximum and minimum systolic blood pressure (SBP) were, respectively, $137 \pm 36 \mathrm{mmHg}$ and $92 \pm 30 \mathrm{mmHg}$. The average maximum and minimum diastolic blood pressure (DBP) were, respectively, $85 \pm 24 \mathrm{mmHg}$ and $57 \pm 26 \mathrm{mmHg}$. The SBP ranged from 70 to $190 \mathrm{mmHg}$ (mean $132 \pm 17 \mathrm{mmHg}$ ). The DBP ranged from 20 to $110 \mathrm{mmHg}$ (mean 82 $\pm 18 \mathrm{mmHg}$ ). The average variation in SBP and DBP during the first 24 hours of hospital stay was, respectively, $16.6 \pm 13.2 \mathrm{mmHg}$ and $5.5 \pm 7.2$ $\mathrm{mmHg}$. The pulse ranged from 76 to $150 \mathrm{bpm}$ (mean $114 \pm 28 \mathrm{bpm}$ ). The respiratory rate ranged from 20 to $34 \mathrm{ipm}$ (mean $24 \pm 6.7 \mathrm{ipm}$ ). The body temperature ranged from 38.3 to $41.2^{\circ} \mathrm{C}$ (mean $39.05 \pm 0.83^{\circ} \mathrm{C}$ ).

The treatment was supportive and consisted of symptomatic medications, such as antipyretics, sedatives and fluid replacement. Hyperimmune globulin was also used. None of the patients received post-exposure vaccine. The immediate cause of death was respiratory insufficiency in all cases.

Table 1

Clinical and laboratory findings at hospital admission of nine patients with rabies

\begin{tabular}{|c|c|c|c|c|c|c|c|c|c|}
\hline Case number & 1 & 2 & 3 & 4 & 5 & 6 & 7 & 8 & 9 \\
\hline Age (years) & 32 & 62 & 15 & 39 & 4 & 3 & 81 & 11 & 40 \\
\hline Sex & $\mathrm{M}$ & $\mathrm{M}$ & $\mathrm{F}$ & $\mathrm{F}$ & M & $\mathrm{M}$ & $\mathrm{F}$ & M & M \\
\hline $\mathrm{SBP}_{\min }-\mathrm{SBP}_{\max }(\mathrm{mmHg})$ & $130-150$ & $130-150$ & $70-170$ & $80-100$ & - & $90-90$ & $40-190$ & $90-100$ & $110-150$ \\
\hline $\mathrm{DBP}_{\min }-\mathrm{DBP}_{\text {max }}(\mathrm{mmHg})$ & $60-90$ & $110-110$ & $40-110$ & $60-60$ & - & $50-50$ & $20-100$ & $50-60$ & $70-100$ \\
\hline $\mathrm{P}_{\min }-\mathrm{P}_{\max }(\mathrm{bpm})$ & $70-90$ & - & $70-90$ & $92-96$ & - & $130-150$ & $67-100$ & $76-120$ & $74-76$ \\
\hline Oliguria & $\mathrm{N}$ & $\mathrm{N}$ & $\mathrm{N}$ & Y & $\mathrm{N}$ & $\mathrm{N}$ & Y & $\mathrm{Y}$ & $\mathrm{N}$ \\
\hline Hematocrit $(\%)$ & 24.4 & - & 30.8 & 43.2 & - & 32.8 & 35.2 & 42.9 & 42.2 \\
\hline Hemoglobin $(\mathrm{g} / \mathrm{dL})$ & 6.7 & - & 10.1 & 14.5 & - & 10.8 & 12.6 & 14.8 & 14.5 \\
\hline White blood cell $\left(\mathrm{x} 10^{3} \mathrm{~mm}^{3}\right)$ & 11.8 & - & 7.6 & 12.3 & - & 7.6 & 14.0 & 11.5 & 6.4 \\
\hline Platelets $\left(\mathrm{X} 10^{3} \mathrm{~mm}^{3}\right)$ & 262 & - & 176 & 213 & - & 397 & 28 & - & 242 \\
\hline Serum urea $(\mathrm{mg} / \mathrm{dL})$ & 25 & - & 21 & 95 & - & 36 & 221 & 102 & - \\
\hline Serum creatinine $(\mathrm{mg} / \mathrm{L})$ & 0.9 & - & 0.8 & 2.0 & - & 0.7 & 2.2 & 1.5 & - \\
\hline Serum sodium $(\mathrm{mEq} / \mathrm{L})$ & 140 & - & 133 & 144 & - & 131 & 127 & 150 & - \\
\hline Serum potassium $(\mathrm{mEq} / \mathrm{L})$ & 3.7 & - & 3.8 & 3.2 & - & 3.3 & 4.5 & 4.6 & - \\
\hline
\end{tabular}

SBP = Systolic Blood Pressure (maximum and minimum), DBP = Diastolic Blood Pressure (maximum and minimum) and P = Pulse (maximum and minimum). 
The autopsy findings are summarized in Table 2. At gross examination of the kidneys no alterations were found. The weight was within normal values. Microscopy showed mild to moderate glomerular congestion and mild to intense peritubular capillary congestion (Fig. $1-\mathrm{A})$, seen in all cases. No alterations in mesangial matrix and cellularity or even in capillary loops were observed. Mild hydropic degeneration and mild tubular regeneration were seen in two cases. Acute tubular necrosis (ATN) was found in only two cases (Fig. 1-B).

None of the cases presented interstitial fibrosis. Inflammatory infiltrate was seen in one case. Arteries showed mild to moderate congestion. Renal medulla showed congestion in four cases. Mild glomerular sclerosis, with benign vascular nephrosclerosis and focal interstitial lymphomononuclear inflammatory infiltrate was seen in one case (81-year-old patient).

The patients who presented high levels of urea and creatinine (cases 4, 7 and 8) were also oliguric, which suggests acute renal failure, but the autopsy findings showed ATN only in case 8. In the other case in which ATN was found the serum creatinine level at admission was

Table 2

Histopathologic features of kidneys from nine patients with rabies found at autopsy

\begin{tabular}{|c|c|c|c|c|}
\hline Case Number & Glomeruli & Tubules & Interstitium & Arteries \\
\hline 1 & $\begin{array}{l}\text { Moderate congestion } \\
\text { Mesangial matrix without alterations } \\
\text { Normal cellularity } \\
\text { Thin capillary loops }\end{array}$ & Mild ATN & $\begin{array}{l}\text { Intense congestion of } \\
\text { peritubular capillaries } \\
\text { Absent inflammatory infiltrate } \\
\text { Absent fibrosis }\end{array}$ & $\begin{array}{c}\text { Mild } \\
\text { congestion }\end{array}$ \\
\hline 2 & $\begin{array}{l}\text { Mild congestion } \\
\text { Mesangial matrix without alterations } \\
\text { Normal cellularity } \\
\text { Thin capillary loops }\end{array}$ & $\begin{array}{l}\text { Mild tubular } \\
\text { regeneration }\end{array}$ & $\begin{array}{l}\text { Moderate congestion of } \\
\text { peritubular capillaries } \\
\text { Absent inflammatory infiltrate } \\
\text { Absent fibrosis }\end{array}$ & $\begin{array}{c}\text { Mild } \\
\text { congestion }\end{array}$ \\
\hline 3 & $\begin{array}{l}\text { Mild congestion } \\
\text { Mesangial matrix without alterations } \\
\text { Normal cellularity } \\
\text { Thin capillary loops }\end{array}$ & $\begin{array}{l}\text { Mild tubular } \\
\text { regeneration }\end{array}$ & $\begin{array}{l}\text { Moderate congestion of } \\
\text { peritubular capillaries } \\
\text { Absent inflammatory infiltrate } \\
\text { Absent fibrosis }\end{array}$ & $\begin{array}{c}\text { Mild } \\
\text { congestion }\end{array}$ \\
\hline 4 & $\begin{array}{l}\text { Mild congestion } \\
\text { Mesangial matrix without alterations } \\
\text { Normal cellularity } \\
\text { Thin capillary loops }\end{array}$ & No alterations & $\begin{array}{l}\text { Moderate congestion of } \\
\text { peritubular capillaries } \\
\text { Absent inflammatory infiltrate } \\
\text { Absent fibrosis }\end{array}$ & $\begin{array}{c}\text { Mild } \\
\text { congestion }\end{array}$ \\
\hline 5 & $\begin{array}{l}\text { Moderate congestion } \\
\text { Mesangial matrix without alterations } \\
\text { Normal cellularity } \\
\text { Thin capillary loops }\end{array}$ & No alterations & $\begin{array}{l}\text { Moderate congestion of } \\
\text { peritubular capillaries } \\
\text { Absent inflammatory infiltrate } \\
\text { Absent fibrosis }\end{array}$ & $\begin{array}{c}\text { Mild } \\
\text { congestion }\end{array}$ \\
\hline 6 & $\begin{array}{l}\text { Moderate congestion } \\
\text { Mesangial matrix without alterations } \\
\text { Normal cellularity } \\
\text { Thin capillary loops }\end{array}$ & No alterations & $\begin{array}{l}\text { Moderate congestion of } \\
\text { peritubular capillaries } \\
\text { Absent inflammatory infiltrate } \\
\text { Absent fibrosis }\end{array}$ & $\begin{array}{l}\text { Moderate } \\
\text { congestion }\end{array}$ \\
\hline 7 & $\begin{array}{l}\text { Mild congestion } \\
\text { Mesangial matrix without alterations } \\
\text { Normal cellularity } \\
\text { Thin capillary loops } \\
\text { Some sclerosing glomeruli }\end{array}$ & $\begin{array}{l}\text { Mild hydropic } \\
\text { degeneration }\end{array}$ & $\begin{array}{l}\text { Moderate congestion of } \\
\text { peritubular capillaries } \\
\text { Focal lymphomononuclear } \\
\text { inflammatory infiltrate } \\
\text { Absent fibrosis }\end{array}$ & $\begin{array}{c}\text { Nephrosclerosis } \\
\text { benign } \\
\text { Moderate } \\
\text { congestion }\end{array}$ \\
\hline 8 & $\begin{array}{l}\text { Moderate congestion } \\
\text { Mesangial matrix without alterations } \\
\text { Normal cellularity } \\
\text { Thin capillary loops }\end{array}$ & Mild ATN & $\begin{array}{l}\text { Moderate congestion of } \\
\text { peritubular capillaries } \\
\text { Absent inflammatory infiltrate } \\
\text { Absent fibrosis }\end{array}$ & $\begin{array}{c}\text { Mild } \\
\text { congestion }\end{array}$ \\
\hline 9 & $\begin{array}{l}\text { Moderate congestion } \\
\text { Mesangial matrix without alterations } \\
\text { Normal cellularity } \\
\text { Thin capillary loops }\end{array}$ & $\begin{array}{l}\text { Mild hydropic } \\
\text { degeneration }\end{array}$ & $\begin{array}{l}\text { Moderate congestion of } \\
\text { peritubular capillaries } \\
\text { Absent inflammatory infiltrate } \\
\text { Absent fibrosis }\end{array}$ & No alterations \\
\hline
\end{tabular}

ATN $=$ acute tubular necrosis. 


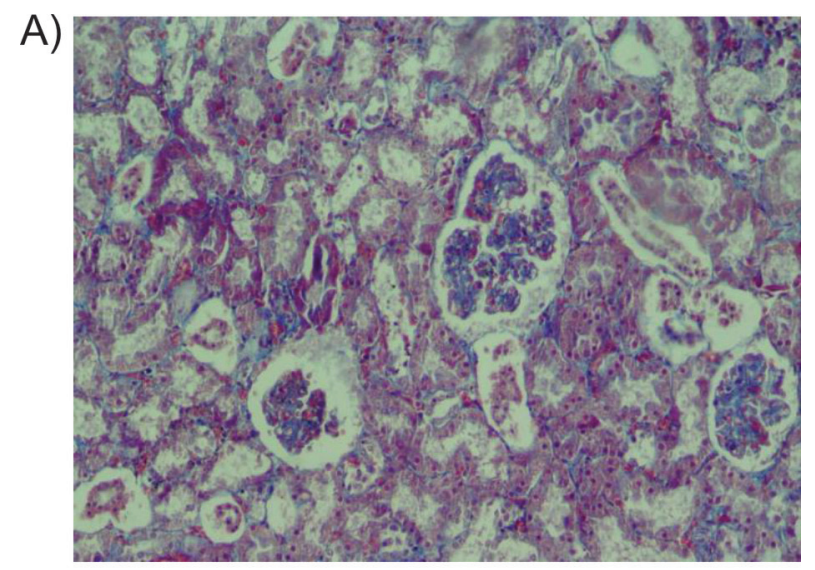

B)

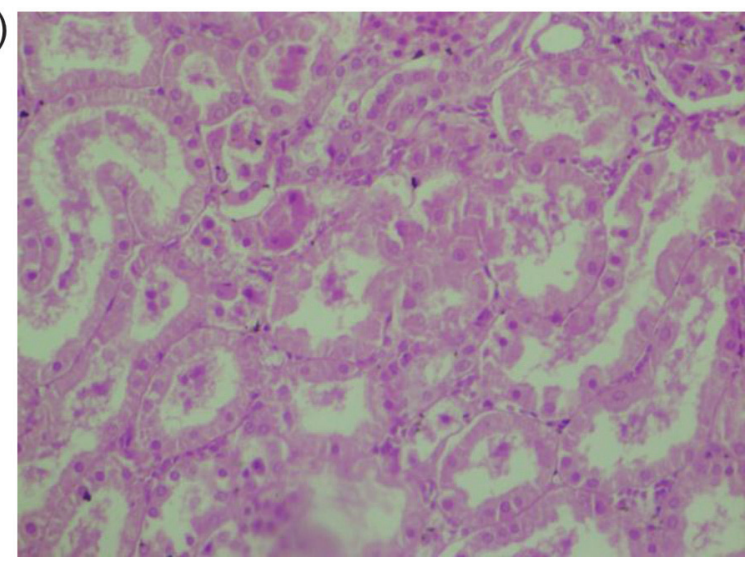

Fig 1. Histopathologic features of kidneys in human rabies. A - Section of kidney showing moderate congestion of glomeruli and peritubular capillaries. B - Section of kidney showing tubular necrosis. H\&E, 200X.

normal, showing that these patients possibly developed ARF during hospital stay.

\section{DISCUSSION}

Rabies is the most important viral zoonosis in the world and, although preventable, still remains an important cause of death in humans, particularly in developing countries ${ }^{2,17,21,25}$. In the cases presented here all the victims were bitten by dogs. The patient's age varied from three to 81 years old, showing that people of all ages are exposed to dog bites in our region. Approximately $40 \%$ of reported dog bites worldwide occur in children, and the majority occur in the face, neck and head ${ }^{3,24}$. In the present study, children comprised one third of the cases. The disease occurred more frequently in males, showing that men are more at risk.

The socioeconomic class of all these patients was very low, consequently we can affirm that rabies occurs in our region due to a lack of information about the available vaccines, which could efficiently prevent development of the disease. Another possibility for the occurrence of rabies is the non-recognition of the disease by the physicians and insufficient advice regarding vaccination. An emerging pattern in the epidemiology of human rabies is lack of clinical suspicion of the disease and a delay in diagnosis ${ }^{16}$. In developing countries deaths occur mainly due to a lack of access to biological agents needed for effective post-exposure prophylaxis ${ }^{19}$.

The diagnosis of the cases presented here was achieved through clinical and epidemiologic data (all the patients had a history of dog bites) and through laboratory tests (immunofluorescence test in the saliva), which was positive in all the cases. Autopsy confirmed the diagnosis through the demonstration of characteristic features of rabies in the patients' tissues (Negri's bodies). The gold standard diagnosis is through direct immunofluorescence test, and the definitive test involves examination of brain tissues ${ }^{19,21}$.

Rabies is an unpredictable disease ${ }^{21}$. The prodromal stage begins when the virus moves centripetally from the periphery to dorsal-root ganglia, causing neuropathic pain, and to the central nervous system ${ }^{10}$. The symptoms in that phase are non-specific and variable, such as burning sensation in the skin, paresthesias, numbness, tingling, itching or pruritus ${ }^{10,12}$.

During the acute neurological phase, objective signs of nervous system dysfunction begin. Two-thirds of patients with classic rabies have an encephalitic form, and the remainder present with paralysis ${ }^{10}$. The earliest feature of the encephalitic rabies is hyperactivity, aggravated by thirst, fear, light, noise and other stimuli. Fever is constant, persisting through the preterminal phase ${ }^{10}$. Within 24 hours, three major cardinal signs follow: fluctuating consciousness, phobic or inspiratory spasms, and autonomic stimulation signs. Mental status alternates between normal periods and progressively more severe agitation and depression. Irritability is gradually followed by deterioration of consciousness and coma ${ }^{10}$. Hyponatremia is present in most cases and is due to inadequate salt intake or the syndrome of inappropriate secretions of antidiuretic hormone ${ }^{10}$. Hypernatremia and polyuria are $\operatorname{rare}^{10}$. Serum sodium above $145 \mathrm{mEq} / \mathrm{L}$ was observed in one of the cases presented here (case 8). Major cardinal signs include low-grade fever, anorexia, paresthesias, ataxia, anxiety, altered mental status and, inevitably, paralysis, coma and death ${ }^{21}$.

The patients of the present study had fever, hydrophobia, agitation, aerophobia, disorientation, dyspnea and, less frequently, sialorrhea, vomiting, oliguria, hematuria, sore throat, pain, hypoestesia in the site of the bite, headache, syncope, cough, hematemesis, mydriasis and cervical pain. This demonstrates the large spectrum of the clinical presentation of rabies, which justifies the non-recognition of the disease in some occasions, particularly when there is no evidence of an accident involving the bite of a possible transmitter of rabies. The absence of a history of exposure to a rabid animal can not exclude the disease, particularly in endemic areas, where exposure is common ${ }^{10}$. The physical examination of our patients showed tachycardia, high pulse rate, high respiratory rate and elevation of body temperature in all cases.

The blood count showed a decrease of hemoglobin in some cases and a normal white blood cell count. The platelets count was low in only one case. The urea and creatinine serum levels were elevated in three cases that also presented oliguria.

The time between the accident and seeking medical care was long 


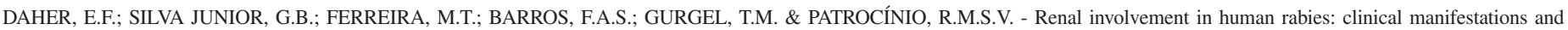
autopsy findings of nine cases from northeast of Brazil. Rev. Inst. Med. trop. S. Paulo, 47(6):315-320, 2005.

in the majority of cases, with a mean of more than one month (estimated incubation period of 45 days). The incubation period of rabies is variable, ranging from less than seven days to over six years ${ }^{10}$. In a study performed in USA, the mean incubation period was 85 days (range 53 to 150 days) and the mean time between the onset of symptoms and hospitalization was four days (range one to 10 days) ${ }^{16}$. The hospital stay in our study was very low, because of the high lethality of rabies. All the patients died just a few days after admission (maximum nine days). Most patients with the encephalitic form of rabies die within seven days (average five days) of onset, and the average survival period is about two weeks in paralytic cases ${ }^{10}$. Rabies survivors have atypical presentations $s^{1,9,10,20}$. No effective treatment has proven successful once clinical signs occur ${ }^{21}$.

The involvement of extra-neural organs in rabies has been described before. In a post-mortem analysis of 14 cases of pediatric and adult cases of rabies from Mexico and $\mathrm{China}^{11}$, rabies virus antigen was found in nerve plexuses in multiple organs, including the gastrointestinal tract, muscle fibers of the heart, tongue and larynx. It has also been frequently find in the adrenal medulla, with an associated inflammatory reaction. Rabies virus can infect a great variety of neuronal and non-neuronal cells in vitro. Non-specific viral attachment to several types of cell-surface receptors including carbohydrates, phospholipids and sialylated gangliosides has been demonstrated ${ }^{23}$. Once the virus enters the peripheral nerves it travels towards the central nervous system via the motor and sensory axons ${ }^{25}$. After the development of the central nervous system infection, there is centrifugal spread of the rabies virus to extra-neural organs. The virus deposits in many tissues, including skeletal and cardiac muscle, adrenal glands, pancreas and nerves around hair follicles. The distribution pattern and susceptibility of any individual organ to the virus of rabies are still unknown ${ }^{11,22}$. Renal involvement in rabies has not been demonstrated before. Acute renal failure in rabies seems to be rare, with few documented cases of oliguria, without demonstration of alterations in serum creatinine or glomerular filtration rate r.13 $^{4}$ It is not known if the virus itself can directly damage the kidneys.

The autopsy findings from our patients showed renal abnormalities in all cases. The most common finding was glomerular congestion. Acute tubular necrosis was found in two cases (case 1 and 8). Serum creatinine at admission of these patients was 0.9 and $1.5 \mathrm{mg} / \mathrm{dL}$, respectively. Case 1 had no sign of acute renal failure, he had no oliguria and his serum creatinine was normal, so that the ATN seen in autopsy could be due to ARF developed after the first day of hospitalization or due to post-mortem degeneration of renal tubular cells. The patients who presented elevated levels of serum creatinine at admission (cases 4, 7 and 8) were oliguric and only case 8 had acute tubular necrosis, suggesting that the first two cases had pre-renal ARF and received a correct treatment with fluid infusion and maintenance of adequate arterial blood pressure. Case 4 presented congestion in the glomeruli and peritubular capillaries, and case 7 presented hydropic degeneration of the renal tubules, congestion in the glomeruli, peritubular capillaries and medulla and sclerosing glomeruli, the latter possibly being a consequence of age (81-year-old patient). The pre-renal factor seems to be the most responsible for renal dysfunction in rabies, with many contributing factors, including dehydration, fever, hydrophobia, sialorrhea and vomiting. Hemodynamic instability, which could be due to autonomic dysfunction, and hypotension are other important factors that lead to renal failure. In previous studies in which kidney tissue of rabies patients was analyzed no alterations were found ${ }^{11}$. The poor correlation between the clinical and histopathological features are because the laboratory data available were those of the patients at admission. Further laboratory tests were not performed, so we could not determine whether the patients who presented renal alterations in autopsy also presented laboratorial abnormalities.

In other infectious diseases (such as tetanus) the autonomic nervous system overactivity, characterized by intense variations in systolic and diastolic blood pressure, by increased heart rate and elevated metanephrine excretion, was higher in the patients with a glomerular filtration rate $\leq 50 \mathrm{~mL} / \mathrm{min}$, suggesting the role of autonomic dysfunction in the pathogenesis of acute renal failure ${ }^{6}$. In classic rabies there is nervous system dysfunction, with autonomic stimulation signs ${ }^{10}$. Hemodynamic dysfunction seems to be common in rabies, with hypotension being observed in most cases. Circulatory insufficiency is one of the most important causes of death in rabies. Echocardiography shows reduction of the ejection fraction in almost all cases, and the probable mechanisms are direct viral involvement at the sinus or atrioventricular node and myocarditis ${ }^{10}$. In our patients, hypotension was observed in five cases (systolic blood pressure $<100 \mathrm{mmHg}$ ), with important variations in blood pressure (hypertension intercalated with hypotension), which is strongly suggestive of autonomic dysfunction. These abnormalities could be a high risk for developing acute renal failure.

In summary, this study shows some evidence of renal involvement in rabies. The post-mortem analysis of the kidneys showed nonspecific alterations. Hemodynamic instability, caused by autonomic dysfunction, hydrophobia and dehydration (pre-renal factors) must be responsible for the development of acute renal failure observed in some patients. Renal damage directly caused by rabies virus should also not be discarded. It was not possible to detect rabies virus antigens in the analyzed tissues, because of lack of technical support. It was also not possible to perform sequential laboratory analysis of serum and urine from all the patients, which would be important to determine the clinical course of the patients. The exact mechanism of extra-neural involvement in rabies remains unclear. Further studies are required for a better investigation of the pathophysiology of renal and other organ damage in rabies.

\section{RESUMO}

\section{Envolvimento renal na raiva em humanos: manifestações clínicas e achados de autópsia de nove casos do nordeste do Brasil}

Foi realizado estudo retrospectivo de nove casos de raiva internados em um hospital de Fortaleza, Brasil. Autópsia foi realizada em todos os casos. As idades variaram de 3 a 81 anos. Todos foram agredidos por cães. $\mathrm{O}$ tempo entre o acidente e a admissão hospitalar variou de 20 a 120 dias (média de $45 \pm 34$ dias). O tempo de internamento variou de 1 a 9 dias (média de $5.5 \pm 3.1$ dias). Os sinais e sintomas observados foram febre, hidrofobia, aerofobia, agitação, desorientação, dispnéia, sialorréia, vômitos, oligúria, faringite, dor e hipoestesia no local da mordida, cefaléia, síncope, tosse, hematêmese, midríase, hematúria, constipação, dor cervical e priapismo. Em três de seis pacientes $(50 \%)$ 


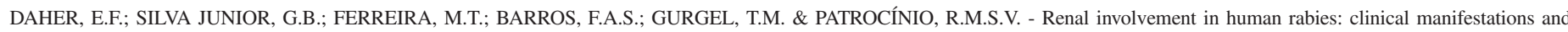
autopsy findings of nine cases from northeast of Brazil. Rev. Inst. Med. trop. S. Paulo, 47(6):315-320, 2005.

foi encontrada evidência de insuficiência renal aguda, definida como creatinina $\geq 1.4 \mathrm{mg} / \mathrm{dL}$. Os achados de autópsia do tecido renal foram congestão glomerular leve a moderada e congestão capilar peritubular leve a intensa. Necrose tubular aguda foi encontrada em dois casos. Estes achados são inespecíficos, de modo que a instabilidade hemodinâmica, causada por disfunção autonômica, hidrofobia e desidratação podem ser considerados como responsáveis pela insuficiência renal aguda na raiva.

\section{REFERENCES}

1. ALVAREZ, L.; CASHAT, M.; ARELLANO, E. \& BAER, G.M. - A new phenomenon in rabies: partial recovery in children treated prompty with potent vaccine. In: INTERNATIONAL MEETING ON ADVANCES TOWARDS RABIES CONTROL IN THE AMERICAS, 7., Atlanta, CDC, 1996. Proceedings. p. 78.

2. BEVILACQUA, S.; RABAUd, C. \& MAY, T. - Rage. EMC-Médecine, 1: 388-392, 2004

3. BHANGANADA, K.; WILDE, H.; SAKOLSATAYDORN, P. \& OONSOMBAT, P. - Dog bite injuries at a Bangkok teaching hospital. Acta trop., 55: 249-255, 1993.

4. BHATT, D.R.; HATTWICK, M.A.W.; GERDSEN, R.; EMMONS, R.W. \& JOHNSON, H.N. - Human rabies. Diagnosis, complications and management. Amer. J. Dis. Child., 127: 862-869, 1974.

5. BRADY, H.R.; CLARKSON, M.R. \& LIEBERTHAL, W. - Acute renal failure. In: BRENNER, B.M. Brenner \& Rector's the kidney. 7. ed. London, Elsevier, 2004. p. $1215-1292$.

6. DAHER, E.F.; ABDULKADER, R.C.; MOTTI, E. et al. - Prospective study of tetanus induced renal dysfunction: role of adrenergic overactivity. Amer. J. trop. Med. Hyg., 57: 610-614, 1997.

7. FISHER, D.J. - Resurgence of rabies: a historical perspective on rabies in children. Arch. Pediat. adolesc. Med., 149: 306-312, 1995.

8. HANLON, C.A.; NIEZGODA, M.; MORRIL, P.A. \& RUPPRECHT, C.E. - The incurable wound revisited: progress in human rabies prevention? Vaccine, 19: 2273-2279, 2001 .

9. HATTWICK, M.A.; WEIS, T.T.; STECHSCHULTE, C.J.; BAER, G.M. \& GREGG, M.B. - Recovery from rabies: a case report. Ann. intern. Med., 76: 931-942, 1972.

10. HEMACHUDHA, T.; LAOTHAMATAS, J. \& RUPPRECHT, C.E. - Human rabies: a disease of complex neuropathogenetic mechanisms and diagnostic challenges. Lancet Neurol., 1: 101-109, 2002.
11. JACKSON, A.C.; YE, H.; PHELAN, C.C.; RIDAURA-SANZ, C. et al. - Extraneural organ involvement in human rabies. Lab. Invest., 79: 945-951, 1999.

12. JACKSON, A.C.; WARRELL, M.J.; RUPPRECHT, C.E. et al. - Management of rabies in humans. Clin. infect. Dis., 36: 60-63, 2003.

13. MATON, P.N.; POLLARD, J.D. \& DAVIS, J.N. - Human rabies encephalomyelitis. Brit med. J., 1: 1038-1040, 1976.

14. MINISTÉRIO DA SAÚDE DO BRASIL. FUNDAÇÃO NACIONAL DE SAÚDE - Guia de vigilância epidemiológica. 5. ed. Brasília, Funasa, 2002. p. 671-704

15. MURPHY, F.A.; HARRISON, A.K.; WINN, W.C. \& BAUER S.P. - Comparative pathogenesis of rabies and rabies-like viruses: infection of the central nervous system and centrifugal spread of virus to peripheral tissues. Lab. Invest., 29: 1-16, 1973.

16. NOAH, D.L.; DRENZEK, C.L.; SMITH, J.S. et al. - Epidemiology of human rabies in the United States, 1980 to 1996. Ann. intern. Med., 128: 922-930, 1998.

17. PARVIZ, S.; CHOTANI, R.; McCORMICK, J.; FISHER-HOCH, S. \& LUBY, S. - Rabies deaths in Pakistan: results of ineffective post-exposure treatment. Int. J. infect. Dis., 8: 346-352, 2004.

18. PASTORET, P.P. - Rabies. Virus Res., 82: 61-64, 2002.

19. PAUL, R. \& O'CONNELL, C.B. - Current approaches to rabies prevention and prophylaxis. J. Amer. Acad. Physician Assist., 15: 16-25, 2002.

20. PORRAS, C.; BARBOZA, J.J.; FUENZALIDA, E. et al. - Recovery from rabies in man. Ann. intern. Med., 85: 44-48, 1976.

21. RUPPRECHT, C.E.; HANLON, C.A. \& HEMACHUDHA, T. - Rabies re-examined Lancet infect. Dis., 6: 327-343, 2002.

22. SRINIVASAN, A.; BURTON, E.C.; KUEHNERT, M.J. et al. - Transmission of rabies virus from an organ donor to four transplant recipients. New Engl. J. Med., 352: 1103-1111, 2005.

23. WARRELL, M.J. \& WARRELL, D.A. - Rabies and other lyssavirus diseases. Lancet, 363: 959-969, 2004.

24. WEISS, H.B.; FRIEDMAN, D.I. \& COBEN, J.H. - Incidence of dog bite injuries treated in emergency departments. J. Amer. med. Ass., 279: 51-53, 1998.

25. WILDE, H.; BRIGGS, D.J.; MESLIN, F.X.; HEMACHUDHA, T. \& SITPRIJA, V. - Rabies update for travel medicine advisors. Clin. infect. Dis., 37: 96-100, 2003.

26. WOLDEHIWET, Z. - Rabies: recent developments. Res. Vet. Sci., 73: 17-25, 2002.

Received: 7 January 2005

Accepted: 7 June 2005 